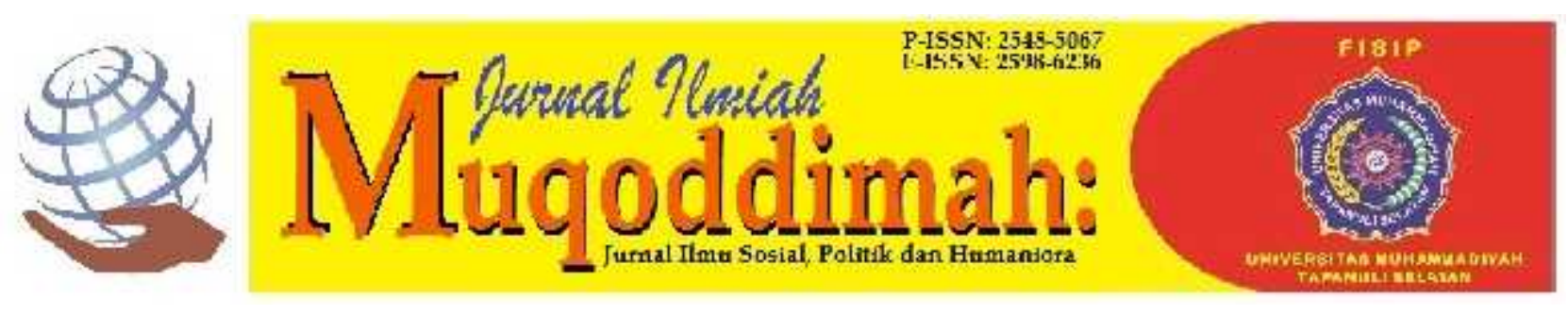

\title{
Dimensional Analysis Organization Design; Case LEMDIKLAT POLRI Training Certification Institute
}

\author{
Fitri Kurnianingsih ${ }^{1)}$, Adi Gunawan Sofwan ${ }^{2)}$, Mahadiansar ${ }^{3)}$ \\ Department Magister Public Administration, Universitas Maritim Raja Ali Haji ${ }^{1)}$ \\ Jalan Raya Dompak, Kota Tanjungpinang 29111. \\ Department Postgruade Public Administration, Universitas Indonesia ${ }^{2)}$ \\ Jl. Pegangsaan Timur No.16 Jakarta 10320 \\ Department Postgruade Public Administration, Universitas Brawijaya ${ }^{3)}$ \\ JI Mt. Haryono No 163 Kota Malang 6514 \\ fitrikurnianingsih@umrah.ac.id ${ }^{1}$ \\ adigunawansofwann@gmail.com² \\ mahadiansar@student.ub.ac.id ${ }^{3}$
}

\begin{abstract}
LSP Lemdiklat Polri has a very strategic role in structuring the management of human resources of the apparatus, especially in ensuring and maintaining the competence of Polri's human resources and other police functions. However, the current organizational structure and work procedures of the National Police Institute of Education and Training are still not in accordance with the workload that must be carried out.Organizational structures are generally an integral part of carrying out their functions and tasks in a structured manner in order to play a role in realizing the vision and mission of the organization itself. Focus and research locus on the analysis of the organizational structure design of the Professional Certification Institute for Education and Training of the Indonesian National Police (LSP LEMDIKLAT POLRI), As for the research method used using literature study based on existing secondary data. The results show that the ideal design of the organizational structure consisting of complexity and centralization and formalization in general, the respondents have a concern for the activities of the LSP LEMDIKLAT POLRI in their environment. The researcher also gives the first conclusion that the LSP LEMDIKLAT POLRI requires improvement in terms of departmentalization and specialization to improve the quality of POLRI personnel, secondly to strengthen regulations and rules as a form of control to ensure and maintain competence in certification services for non-INP police function bearers.
\end{abstract}

Keywords: Design Analysis, Organizational Dimensions, Polri

\section{INTRODUCTION}

Globalization right now significantly affects public and worldwide level security. The pace of dangers that can change in the structure of organizing the framework and example of public safety just as homegrown security specifically. (Maguire, 1997; Nalla \& Mamayek, 2013). Thusly, as an organization approved by law to keep up homegrown security, the Police should have the option to react with the impacts of globalization. As of now the job of the National Police likewise has the attributes of hierarchical advancement that is in accordance with its way towards the World Class Organization (Bayley, 2015; Fyfe, 2014; Juncos, 2011)

As commanded in Law Number 2 of 2002 concerning the National Police that keeping up homegrown security through the organization of the police which incorporates upkeep of safety and public request, law implementation, insurance, assurance and administrations for the local area are important for the POLRI administration exercises as a 
state instrument that helps just as ensuring the local area by regarding and maintaining the nobility of an individual who has common freedoms (Gaussyah et al., 2015).

The National Police, which is one of the state instruments that give police administrations to the local area, is needed to work expertly, straight for wardly and accountably as per the requests and assumptions for the local area just as the standards of good administration and clean government in administration (Susanti, 2007; Yulihasti, 2008). That to accomplish this, the National Police has decided the National Police Grand Strategy for 2005-2025 which is partitioned into 3 (three) key plans, specifically:

a. Strategic Plan I for 2005-2009 which is the Trust Building stage.

b. Strategic Plan II for 2010-2014 which is the Partnership Building stage.

c. Strategic Plan III 2015-2025 which is the Strive for Excellence stage.

In accordance with this, the National Police has likewise carried out regulatory change, which is at present entering its third wave. In any case, the execution of wave II administrative change with the point of making an administration that is perfect and liberated from KKN (Corruption, Collusion and Nepotism) depends on improving the nature of public administrations for the local area and expanding the capacity and responsibility of regulatory execution still not running as indicated by the objective. has been set up. This is expected to, in addition to other things, the deficient game plan of the human asset the board framework for the device (Damanik, 2016).

To help the 2015-2025 National Police Grand Strategy, to be specific the Strive for Excellence stage, the National Police Chief made discoveries as 10 Professional, Modern and Trusted (Promoter) Programs. Two of the ten Promoter Programs referenced underscore the presence of expert improvement endeavors for Polri work force. Expanding the polished skill of the National Police is expressed in Program 4 and Program 9. In Program 4 concerning Increasing the Professionalism of the Police towards Excellence, requires the Police to complete exercises through gathering practical position groups and expert certificate. Program 4 Activities 4 Phase III (2018 to 2019) contains the commitment to do exercises through proceeding to execute proficient certificate for practical positions and completing investigation/assessment.

Law implementation, which is relied upon to be more expert and reasonable in program 9, likewise requires the Police to promptly do certificate of specialized abilities for examiners. Reacting to these difficulties, endeavors that should be made quickly are improving the nature of the HR of the National Police through instruction and preparing just as vocation advancement (arrangement) of staff dependent on foreordained abilities. In this way, presently Polri's schooling and preparing programs require competency-based preparing that adjusts to the competency norms set by the association. In the interim, to guarantee and keep up the fitness of its alumni, it is important to help out competency certificate through a competency test by the Professional Certification Institute (LSP) of the Indonesian Police Education and Training Institute. In the wake of going through the competency test, members who are announced able are given competency endorsements.

Specialists picked LSP LEMDIKLAT as the object of examination in light of the fact that amidst a flood of regulatory change where the National Police was incorporated, the LSP Lemdiklat Polri turned into a vital instrument for Polri in getting ready proficient HR through proficient certificate. Every office is fundamentally organized, in completing its obligations the two elements of preparation, coordinating, coordinating, and controlling are gone before by a game plan in the hierarchical design adjusted to these means. For this situation the hierarchical construction is the main stage used to start the execution of authoritative exercises.

Hierarchical construction is a conventional system, where errands/occupations are plainly separated and can be effortlessly planned depict that there are three scientific measurements in a hierarchical design that have intricacy, formalization, and centralization. Intricacy is an image containing the degree of separation in an association (Robbins \& Coulter, 2007). As a push to improve, it will be persistently improved the construction of 
intricacy in authoritative components (Bayley, 2015) There are three measurements in intricacy, to be specific:

1. Vertical differentiation: this dimension is more of a description of the organizational structure or hierarchy.

2. Horizontal differentiation: this dimension describes the level of horizontal division by units based on the orientation of the members, their level of education and training, and the nature of the tasks carried out. This horizontal differentiation results in a heavier burden for organizational managers to coordinate each organizational activity, and can make communication between units difficult (Kusdi, 2011: 169). The grouping of certain activities specifies roles between individuals in contrast to departmental processes which easily look for organizational ways of organizing activities in a horizontal differentiation process.

3. Spatial differentiation: in this dimension, it describes the prospects for the level of facilities and organizational members who are spread out geographically

Centralization is a methodical and reliable interaction at a focal authority inside an association. Authoritative pioneers can do their work duties better than those of their subordinates. Besides, the authority settles on a choice that is viewed as successful with the laborers. This centralization shows that most choices are made by individuals who are at a higher point in an association, in particular the administration. Centralization is additionally made to encourage individual authority in a little association and to give controlled exercises, and to help dispose of crises. (Allen, 2013:158-159).

When all is said in done, there are various types of authoritative design, where each has shortcomings and qualities. Based on the current connections in the association as (Goold \& Campbell, 2002:150) there are 5 types of hierarchical design, specifically, Line Organization, Line and Staff Organization Form, Functional Organization Form, Line Organization Form, Staff and Functional and Organizational Forms of the Committee.

As a rule, the National Police is as a Line and staff association since all choices, strategies, and acknowledgment of organization goals are in charge. The assignment of power is completed vertically from the most elevated authority to the lower initiative so the rule of solidarity of order stays solid. In the smooth execution of their work obligations, the authority is helped by the staff. The staff can contribute as staff help, musings, ideas and information, give data and information handling, and offer types of assistance to the initiative as info and thought in settling on choices and strategies (Brown \& Duguid, 2001)

In like manner with the Polri Institute of Education and Training as a Line and Staff Organization which has a Staff and Line component, where the Staff Element is entrusted with aiding and providing the necessities of the Internal Organization, both the requirements of the Leaders and the necessities of Line Elements. While the Line Element has the errand of aiding the Leadership do the principle undertakings of the association. LSP is a work unit in the Assistant Leadership and Executive Staff component in the National Police Kalemdilat. Coming up next are the obligations of the LSP, in particular:

1. Administrator of offices for exercises as per the necessities of the kind of skill;

2. Created regarding executing the quality administration framework LSPP-1 or potentially LSPP-2 which is changed in accordance with the BNSP Guidelines 215.

3. Aggregate different capability materials and competency tests;

The LSP Lemdiklat Polri was shaped dependent on the responsibility and honesty of the POLRI to improve the nature of polished methodology for individual POLRI individuals. This expansion was started through the quality affirmation of schooling and preparing for the National Police, which in addition to other things was done with normalization and certificate. To get this going is absolutely not something simple. 
Figure 1.1 Structure of the LSP Institute for the Education and Training POLRI

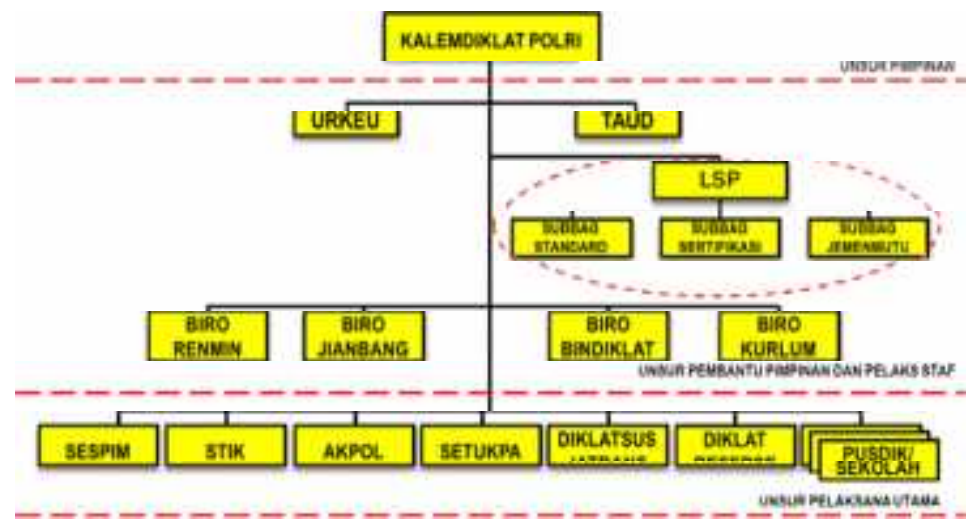

Source: National Police Regulation Number 5 of 2019

Notwithstanding, in light of the Academic Manuscript proposing changes in the Organizational Composition and Governance of the 2018 National Police Institute of Education and Training, as a foundation given the obligations and duties to ensure and keep up the skill of Polri's HR through proficient affirmation, the LSP LEMDIKLAT POLRI has not had the option to do its obligations and obligations. maximally. This is because of a few existing issues, among others, the first is the improper position of the Institute for Education and Training Institute of the Police in the hierarchical design of the National Police Institute, specifically the National Police LSP is set in the administration associate component which ought to be set in the Main Task Force on the Polri Lemdillat structure, while its exercises are a greater amount of an operational nature (Damanik, 2016; Sinaga et al., 2018)

Besides, the second, now, is the top of the National Police Education and Training Institute which is driven straightforwardly by the Kombespol, however prompts the enactment, at that point the LSP Lemdiklat POLRI is doled out to the confirmation for POLRI enrollment from the Tamtama / Bhayangkara Group to the Inspector General of Police, with these contemplations, at that point the Head of the LSP and the assessor will have in any event a similar position as the surveyed assessor. The third is the restricted authoritative assets on the grounds that the current hierarchical design and work methods of the National Police Institute of Education and Training are as yet not as per the responsibility of their obligations and capacities.

Table 1.1 List of Personnel Composition (DSP) LSP Lemdiklat POLRI

\begin{tabular}{|c|c|c|c|c|c|}
\hline No. & Jabatan & Pangkat/Gol & Dsp & Riil & Ket \\
\hline 1. & Kepala Lsp & $\begin{array}{l}\text { Komisaris } \\
\text { Besar Polisi }\end{array}$ & 1 & 1 & \\
\hline 2. & Kasubbag & Akbp & 3 & 3 & \\
\hline 3. & Paurmin & $\begin{array}{l}\text { Komisaris } \\
\text { Polisi / Pns } \\
\text { Gol Iva/B }\end{array}$ & 1 & 1 & Pns (Gol.Iva) \\
\hline 4. & Paur Subbag & $\begin{array}{l}\text { Komisaris } \\
\text { Polisi / Pns } \\
\text { Gol Iva/B }\end{array}$ & 6 & 6 & $\begin{array}{l}\text { - } 1 \text { Polri (Kompol), } \\
\text { - } 5 \text { Pns (1 Orang } \\
\text { Gol.Iva, } 2 \text { Orang } \\
\text { Gol.liic Dan } 2 \\
\text { Orang Gol. liib) }\end{array}$ \\
\hline
\end{tabular}




\begin{tabular}{lllccc} 
5. & Bamin/ Banum & $\begin{array}{l}\text { Bintara / Pns } \\
\text { Gol li/l }\end{array}$ & 4 & 22 & 7 Polri, 15 Pns \\
6 & Non Jabatan & - & - & 1 & Polisi (Akbp) \\
\hline & J U M L A H & & 15 & 33 & \\
\hline
\end{tabular}

\section{Source: LSP Lemdiklat Polri 2019}

Presently, LSP Lemdiklat Polri has a License Certificate as LSP Polri from the National Professional Certification Agency (BNSP) as illustrated in the Decree of the Head of BNSP No: Kep.201/BNSP/IV/2014 dated April 25, 2014, so the LSP Lemdiklat Polri has a legitimate premise in confirming to all individuals from the police. In completing the certificate, LSP Lemdiklat Polri has 1 Master Assessor and 429 Competency Assessors who have gotten authentications from BNSP yet are not lasting faculty/domiciled at the LSP Lemdiklat Polri yet are spread to different capacities in the Police.

As well as doing competency tests at the Internal Police, LSP Lemdiklat Polri as the obligation carrier as LSPP-2 likewise has the commitment to do certificate for Polri's accomplices, specifically the individuals who do other police capacities. In view of the previously mentioned realities, the sorts of skills that should be encouraged and the quantity of possibility for competency testing to be directed are expanding. Accordingly, to conquer these issues, a sufficient authoritative construction as per these requirements, both in amount and quality In view of the examination of the errand load as portrayed above, as far as quality, not the entirety of the faculty relegated to the LSP Lemdiklat Polri are equipped in their particular obligations.

Regarding the depiction that has been clarified, the execution of the LSP undertaking of the POLRI Education and Training Institute is to keep up and guarantee the nature of the POLRI participation capability so it is as arranged, at that point it is important to do a logical investigation of the examination on the construction plan of the POLRI Institute for Education and Training Institute, the investigation of the association utilizing the idea the insightful element of hierarchical design (Robbins, 2003; Yudithia, 2019).In previous research, Manaf (2019) explained that analysis on organizational design affects the work environment on work performance; then the effect of workload on work performance; as well as the influence of the work environment on workload.

The urgency of this research is to identify the condition of the POLRI LEMDIKLAT in the analysis of organizational designs on strengthening quality human resources. In light of the foundation of the issue over, the creators are keen on leading examination on "Investigation of the authoritative construction plan of the Professional Certification Institute for Educational and Training Institutions of the Indonesian National Police". Examination of hierarchical design through the methodology of intricacy, centralization, and formalization is generally utilized for benefit or benefit situated associations, however this is the first run through the intricacy, centralization, and formalization approaches are utilized openly or government association

\section{METHOD}

This type of research is a descriptive study with a qualitative approach. It is called that because this type of research emphasizes (focuses) on efforts to describe the situation as it is (Sugiyono, 2012) where the goal is to produce descriptive data in the form of written or spoken words from people or observable behavior (Bogdan \& Taylor, 1975; Moleong, 2012) which is intended for exploration and classification of a phenomenon or social reality. Therefore qualitative research is often referred to as descriptive research that is non-hypothetical and value-laden (Singarimbun \& Effendi, 2006).

Qualitative researchers study objects in their natural context, seeking to understand and interpret. The phenomenon is seen from the side of the meaning that 
humans (researchers) attach to it. Furthermore, qualitative research includes the use of the subject under study and a collection of various empirical data - case studies, personal experiences, introspection, life experiences, interviews, observational texts, historical, international, and visual - that describe moments and daily meanings. and problematic in one's life (Denzin, 1978; Denzin \& Lincoln, 2005).

This research focuses on data that has been interviewed, theoretical data and questionnaire data to provide an overview of the explanation of the formalization, complexity and centralization of the LSP Lemdiklat Polri based on the perspectives of all members of the LSP Lemdiklat Polri.

\section{RESULTS AND DISCUSSION Complexity Dimensions}

The complexity in this study is defined as the direct growth result of the division of labor. Complexity refers to the level of differentiation that exists within the organization (Johnson, 2009; Saaty, 2001; Zee et al., 2017). Meanwhile, differentiation is basically manifested in two ways, namely departmentalization and specialization. Therefore, in measuring complexity two indicators are used, namely Departmentalization and Specialization. Departmentalization is the way in which an organization is structurally divided. Departmentalization can be used as a measuring tool to see the level of complexity in the organization because departmentalization can describe the large variety of jobs in the organization.

Specialization is the process of forming various tasks so that they are more complex (Ortega et al., 2010; Zayed et al., 2010). Specialization indicates the grouping of certain activities played by one individual (Kusdi, 2011: 169). This indicator is more directed at the division of functions within the organization based on the special skills or specifications that must be possessed in carrying out the job or task. According to the research conducted, it was found that dominating this organization had a variety of jobs to do and had different work routines so that the organizational components encountered many special events outside their routine activities in their work. But the organizational component, in general, will quickly find out what to do with the confidence that the effort will be successful. Therefore, sometimes in carrying out daily tasks, organizational components must use different methods or procedures to carry out their work.

\section{Formalization Dimensions}

Formalization in this investigation is characterized as how much principles, methods, guidelines, and correspondence are composed (Freese, 1981; Ortega et al., 2010). So in estimating the components of formalization, four estimation pointers are utilized as follows:

1. Set of working responsibilities is utilized to perceive how far the association decides the exercises or capacities that should be performed by every individual or part of the association.

2. Composed guidelines that are possessed by the association. Guidelines will give direction to hierarchical parts on what to do and what not to do, moreover, guidelines will give composed direction on how all authoritative segments ought to together accomplish authoritative objectives.

3. The method gives a composed portrayal of the authoritative interaction stream, just as the stages that every individual from the association should go through from the information sources, cycles, and yields the association needs to accomplish.

4. Composed (official) records are utilized as an estimating device to what the degree of the degree of formalization in the association. Composed archives, for this situation, are for the most part official records of both individual and division 
execution, composed reports, and other authority records identifying with the exercises of the association overall.

As indicated by research led, the degree of formalization of an association shows the viewpoint of the chiefs in the association according to the individuals from the association. In the event that individuals from the association are considered to have no capacity or power to do choices and are less ready to regulate themselves appropriately, at that point the formalization of the association will in general be high. This is in accordance with the individuals from the LSP Lemdiklat Polri association where they should submit to the set up guidelines and follow work techniques cautiously. Each individual from the association isn't excessively checked on the off chance that they disregard strategies or don't keep the principles since this association has adequate composed information with respect to the presentation of every part. Consequently, authoritative individuals should comprehend and submit to the principles that have been set so the pioneers don't actually need to notice and direct them.

\section{Centralization Dimensions}

Centralization is used by two indicators at the National Police Institute of Education and Training LSP, namely:

1. The hierarchy of organizational decisions is used to see to what extent the organization of the LSP Lemdiklat Polri places decision-making authority in the organization, meaning that this indicator tries to see the decision-making authority in the organization and how strong the role of the leader is in making organizational policies down to even the smallest things.

2. Delegation of authority used to measure the distribution of decision-making authority within the organization.

These two indicators provide an overview of how far decision-making authority is given in the organization and what types of decisions are taken centrally or are decentralized at lower organizational levels. Centralization is closely related to the distribution of power in organizations, especially in relation to organizational structures. There are many views regarding this centralization, as stated by (Ortega et al., 2010) which states that centralization refers to the level at which decision making is centralized to a leader in the organization. igh concentrations indicate high centralization, while low concentrations indicate low centralization or what is called centralization.

According to the research conducted, in the LSP Lemdiklat Polri, there are many types of decisions that must be taken by the leadership which states that there are many types of decisions that must be taken by the leadership, in this organization very few activities can be carried out without prior approval by the leadership. However, in certain circumstances, members of this organization participate in making decisions regarding the determination of a new program through open meetings.

\section{CONCLUSION}

This research was conducted to analyze the complexity, formalization, and centralization of the current organizational structure of the Institute for Professional Certification of the Indonesian Police Education and Training Institute as well as to analyze the organizational structure of the Institute for Professional Certification of the Indonesian National Education and Training Institute. Based on the results of data processing and analysis described in the previous chapter regarding the analysis of the organizational structure of the Institute for Education and Training Polri based on the point of view of each employee, the researcher can draw some conclusions that can provide answers to the first objective in this study, namely the departmental aspect as indicated by the large variety of jobs at the LSP Lemdiklat Polri, then the specialization aspect which is shown by the division of functions at the LSP Lemdiklat based on 
special expertise or specifications that must be possessed in carrying out certain jobs or tasks that are played by one individual.

Then the application of the concept of structure in an organization is very much determined by many aspects and requires a more comprehensive study from both a macro and micro organizational point of view. There are still many dimensions that need to be included in order to describe the organizational structure. For this reason, further research needs to be carried out with a broader scope by including other dimensions, both from the structural and contextual dimensions of the organization, which are not yet in this study. In addition, it is necessary to carry out a broader and deeper theoretical study so that other dimensions can be found that can be included in the analysis in order to obtain a more perfect and comprehensive picture of the organizational structure.

\section{ACKNOWLEDGEMENT}

Thanks we give to the reviewer Jurnal IImiah Muqoddimah: Jurnal IImu Sosial, Politik dan Hummaniora already providing input in the form of criticism and suggestions to the author that this article could be published in issue number 2 vol 52021

\section{REFERENCES}

Allen, L. A. (2013). Management and organization (Davis K, Ed.).

Bayley, D. (2015). Police research: Trends and prospects. In R. Granér \& O. Kronkvist (Eds.), The Past, the Present and the Future of Police Research (p. 279). Polisutbildningen och författarna.

Bogdan, R., \& Taylor, S. J. (1975). Introduction to Qualitative Research. In Wiley.

Brown, J. S., \& Duguid, P. (2001). Knowledge and Organization: A Social-Practice Perspective. Organization Science, 12(2), 198-213. https://doi.org/10.1287/orsc.12.2.198.10116

Damanik, R. M. (2016). Upaya POLDA Kalimantan Barat dalam penerapan peraturan pemerintah nomor 2 tahun 2003 tentang peraturan disiplin bagi anggota POLRI guna mewujudkan Good Governance dan Clean Goverment di Internal POLRI. Jurnal Nesto Magister Hukum, 1(1), 1-16.

Denzin, N. (1978). The research act: A theoretical introduction to sociological methods (2nd ed.). McGraw-Hill.

Denzin, N., \& Lincoln, Y. (2005). The SAGE Handbook of Qualitative Research (Third Edition). SAGE.

Freese, L. (1981). The formalization of theory and methode. American Vehavior Sciences, 24(3), 345-363.

Fyfe, N. (2014). Observations on police reform in Scotland. British Society of Criminology Newsletter, 1(74), 8-12.

Gaussyah, Damanik, I., Muhammad, I., \& Bakhry, S. (2015). Mewujudkan POLRI yang profesional melalui penguatan tata kelola: Indeks tata kelola Kepolisian Negara Republik Indonesia. Astana Communication.

Goold, M., \& Campbell, A. (2002). Do you have a well-designed organization? In Harvard Business Review.

Johnson, N. F. (2009). Two Company, Three is Compelexity. In Simply complexity: A clear guide to complexity theory (pp. 3-undefined). Oneworld Publications.

Juncos, A. E. (2011). Europeanization by decree? The case of police reform in Bosnia. Journal of Common Market Studies, 49(2), 367-389.

Manaf, A., Matin, M., \& Zulaikha, S. (2019). Effect of Work Environment and Work Loads on the Performance of Police Educators in Sepolwan Lemdiklat Polri. International Journal for Educational and Vocational Studies, 1(5), 461-466.

Maguire, E. R. (1997). Structural change in large municipal police organizations during the community policing era. Justice Quarterly, 14(3), 548-576. 
Moleong, L. J. (2012). Metodelogi penelitian kualitatif. Remaja Rosdakarya.

Nalla, M. K., \& Mamayek, C. (2013). Democratic policing, police accountability, and citizen oversight in Asia: An exploratory study. Police Practice and Research An Internasional Journal, 14(2), 117-129.

Ortega, E. M. P., Saez, P. Z., \& cortes, E. C. (2010). Can formalization, complexity, and centralization influence knowledge performance? Journal of Business Research, 63(3), 310-320. https://doi.org/10.1016/j.jbusres.2009.03.015

Robbins, S. P. (2003). Organizational behavior. Prentice Hall.

Robbins, S. P., \& Coulter, M. K. (2007). Management (9th ed.). Pearson Prentice Hall.

Saaty, T. (2001). The analytic network process: The organization and prioritization of complexity. In Decision Making with Dependence and Feedback (p. 370). Rws Publications.

Sinaga, S., Salim, S. R. A., \& Absah, Y. (2018). The Effect Of Education And Training (Total) On Education: Performance Through Education Competency With Organization Support As Variable Moderating On School Country Police (Spn) Polda Sumut. https://doi.org/10.2991/ebic-17.2018.61

Singarimbun, M., \& Effendi, S. (2006). Metode penelitian survei. PT Pustaka LP3ES Indonesia.

Sugiyono. (2012). Metode penelitian kuantitatif, kualitatif, dan R\&D. Alfabeta.

Susanti, D. (2007). Hubungan antara kecerdasan emosional dengan profesionalisme pada polisi fungsi samapta kepolisian wilayah kota besar Semrang.

Yulihasti, E. (2008). Bekerja Sebagai Polisi. Erlangga Mahameru.

Yudithia, Y., \& Mahadiansar, M. (2019). Perilaku Organisasi Positif dalam Kinerja Pegawai; Suatu Konsep dan Teori.

Zayed, M. J., Nouvel, N., Rauwald, U., \& Scherman, O. A. (2010). Chemical complexity-supramolecular self-assembly of synthetic and biological building blocks in water. Chemical Society Reviews, 39(8), 2806-2816. https://doi.org/10.1039/b922348g

Zee, E. van der, Gerrets, A. M., \& Vanneste, D. (2017). Complexity in the governance of tourism networks: Balancing between external pressure and internal expectations. Journal of Destination Marketing and Management, 6(4), 296-308. https://doi.org/10.1016/j.jdmm.2017.07.003 